\title{
Pharmacological Properties of Bivalent Ligands Containing Butorphan Linked to Nalbuphine, Naltrexone and Naloxone at $\mu$, $\delta$ and $k$ Opioid Receptors
}

\author{
Xuemei Peng ${ }^{\dagger}$, Brian I. Knapp ${ }^{\ddagger}$, Jean M. Bidlack ${ }^{\ddagger}$, and John L. Neumeyer ${ }^{\dagger,}{ }^{\star}$ \\ Alcohol and Drug Abuse Research Center, McLean Hospital, Harvard Medical School, 115 Mill \\ Street, Belmont, Massachusetts 02478 and Department of Pharmacology and Physiology, \\ University of Rochester, School of Medicine and Dentistry, Rochester, New York 14642 \\ †Harvard Medical School

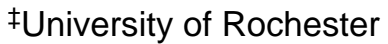

\begin{abstract}
Investigation of bivalent ligands at $\mu, \delta$ and $\kappa$ opioid receptors is now focused on the preparation of ligands containing $\kappa$ agonist and $\mu$ agonist/antagonist pharmacophores at one end joined by a linking chain containing the $\mu$ antagonists pharmacophores (naltrexone, naloxone or nalbuphine) at the other end. These ligands were evaluated in-vitro by their binding affinity at $\mu, \delta$ and $\kappa$ opioid receptors and their relative efficacy in the $\left[{ }^{35} \mathrm{~S}\right] \mathrm{GTP} \gamma \mathrm{S}$ assay.

Ligands 6-8 displayed better or the same affinity at $\kappa$ and $\mu$ receptors compared to the monovalent ligands 1-5. Ligands 6-8 generally showed reduced affinity at $\delta$ receptor compared to the monovalent ligands 1-5. Functional assays showed that the ligand $\mathbf{6}$ was a $x$ agonist/antagonist and $\mu$ antagonist whereas ligands $\mathbf{7}$ and $\mathbf{8}$ were $\kappa$ agonists and $\mu$ agonists/antagonists.
\end{abstract}

\section{Introduction}

The heterodimerization of G-protein coupled receptors has important implications because it represents another mechanism that could modulate receptor function and suggests additional targets for drug development. ${ }^{1-3}$ There is now an increasing realization that activity at a single receptor is insufficient for modulating multiple targets for the treatment of a range of disorders. ${ }^{4}$ Bivalent ligands have been developed for a variety of G-protein coupled receptor targets including opioid ${ }^{5,6}$ adrenergic, ${ }^{7}$ dopamine, ${ }^{8}$ serotonin, ${ }^{9}$ muscarinic receptors,,${ }^{10}$ but also enzymes such as butyrylcholinesterase. ${ }^{11}$ The methodical combination of pharmacophores from selective ligands that act on specific targets (receptors) is an important technique used for the generation of bivalent ligands. There is the possibility that the development of bivalent ligands in the opioid field which bridge the gap between binding sites on dimerized receptors will lead to a new generation of analgesic drugs that may not cause physical dependence or tolerance with chronic use. ${ }^{12}$

Previous reports from our laboratories indicated that the mixed action of the $\kappa / \mu$ agonist butorphan (1) has a more promising profile of activity than the $\kappa$ agonist/ $\mu$ antagonist cyclorphan. ${ }^{13,14}$ This finding led to the synthesis of a series of homo-bivalent ligands incorporating butorphan (1) as the pharmacophore connected by linking spacers of varying lengths. ${ }^{15,16}$ It was observed that the affinity of these ligands was sensitive to the character

*To whom correspondence should be addressed. Phone: 617-855-3388. Fax: 617-855-2519. Neumeyer@mclean.harvard.edu. 
and length of the spacer. The homobivalent ligand $\mathbf{9}$ containing butorphan (1) at both ends of the 10-carbon linking ester chain (Figure $\mathbf{1})(K \mathbf{i}=0.09 \mathrm{nM}$ at $\mu$ and $0.049 \mathrm{nM}$ at $x)$ was the most potent ligand in this series. ${ }^{15,16}$ In the course of the synthesis of a series of heterobivalent ligands containing butorphan (1) at one end and other pharmacophores at the other end of the linker, we also found that the stereochemistry of the pharmacophores, the $\mathrm{N}$ substituents of the pharmacophore, ester linkages and the spacer lengths were crucial factors for optimum interactions of such ligands at opioid receptor binding sites. ${ }^{17}$ The spacer length for these compounds was dictated by the peak potency that was observed when sebacoyl ester (10 carbon) unit was incorporated into the molecule. A multiple ligand $\mathbf{1 0}$ (Figure 1) derived from the linkage of a $\delta$ selective peptide antagonist Dmt-Tic ( $2^{\prime} 6^{\prime}$ dimethyl- $L$-tyrosine-1,2,3,4-tetrahydroisoquinoline-3-carboxylic acid) and a $\mu / \kappa$ morphinan agonist butorphan (1) through a two-methylene spacer was found to maintain exactly the same characteristics as the two reference compounds. ${ }^{18}$

Portoghese et al. has also reported a range of homo and hetero dimeric ligands with varying linker lengths designed to investigate pharmacodynamic and organizational features of opioid receptors. ${ }^{19}$ For example, recently reported heterodimeric ligands containing $\delta$ antagonist (naltrindole) and $\boldsymbol{\kappa}$ agonist (ICI-199,441) pharmacophores joined by variable length oligoglycyl-based linkers were demonstrated to possess significantly greater potency and selectivity when compared to their monomer congeners providing further evidence for the opioid receptor hetero-oligomerization phenomena. ${ }^{20}$

In order to further investigate opioid bivalent ligands containing pharmacophores that have established $\kappa / \mu / \delta$ affinity, a combination of agonist and antagonist pharmacophores was employed in the design of bivalent ligands for exploring the interaction between receptors. Here we report the synthesis of three heterodimeric ligands derived from the linkage via a 10 carbon spacer of the $\mu$ antagonists nalbuphine (2), naltrexone (3) or naloxone (4) and a $\mu / \kappa$ agonist butorphan (1).

\section{Chemistry}

The heterodimeric ligands 6,7 and 8 were prepared by condensing the acid 5 with either nalbuphine (2), natrexone (3) or naloxone (4) in the presence of DCC and DMAP as previously reported (Figure 1). ${ }^{17}$

\section{Pharmacological Results and Discussion}

\section{Affinity and Selectivity of the Synthesized Ligands}

All the novel heterodimer ligands were evaluated for their affinity at and selectivity for $\mu, \delta$ and $x$ human opioid receptors with Chinese hamster ovary $(\mathrm{CHO})$ cell membranes stably expressing one of the human opioid receptors. The data are summarized in Table 1. For comparison purposes, opioid binding affinity data for butorphan (1), nalbuphine (2), naltrexone (3) and naloxone (4) are included in Table 1. The monovalent ligand $\mathbf{5}$ and the homobivalent ligand 9 reported previously ${ }^{17}$ were also included in order to evaluate the contribution of the spacer itself or the pharmacophores to binding.

Heterodimeric compounds such as 6 (butorphan (1) combined with nalbuphine (2)), 7 (butorphan (1) combined with naltrexone (3)) and $\mathbf{8}$ (butorphan (1) combined with naloxone (4)) with a 10-carbon linking ester, displayed slightly better affinity at $\mu$ (around 2 fold) compared to the monovalent ligand 5. Compound 7 (butorphan (1) combined with naltrexone (3)) and $\mathbf{8}$ (butorphan (1) combined with naloxone (4)) showed lightly better affinity at $\mathcal{K}(\sim 2$ fold) receptor while compound $\mathbf{6}$ (butorphan (1) combined with nalbuphine (2)) retained same affinity at $\boldsymbol{\kappa}$, but all had lower affinity than butorphan (1). From the data 
shown in table 1, the heterodimer 6 (containing butorphan (1) and nalbuphine (2)) showed increased affinities both at $\mu(K i=0.46 \mathrm{nM})$ and a 6 fold increase $(K i=0.34 \mathrm{nM})$ at $\kappa$ receptors compared to nalbuphine (2), while the affinity at $\delta$ receptor was an average of the two monomeric ligands $\mathbf{1}$ and $\mathbf{2}$. Similarly, the heterodimer $\mathbf{8}$ (containing butorphan (1) at one end and naloxone (4) at the other), displayed a 2 fold increase at $\mu(K i=0.43 \mathrm{nM})$ and a 10 fold increase at $\kappa$ receptors $(K i=0.13 \mathrm{nM})$ as well as 2 fold increase at $\delta$ receptor compared to naloxone (4). It is interesting to note that compound 7 (containing butorphan (1) and naltrexone (3)) displayed almost identical affinities at all three opioid receptors as the monomer naltrexone.

\section{Efficacy of Selected Ligands}

To characterize the relative efficacy of the ligands, butorphan (1), nalbuphine (2) and monovalent ligand $\mathbf{5}$ were selected for the $\left[{ }^{35} \mathrm{~S}\right] \mathrm{GTP} \gamma \mathrm{S}$ assay. Table 2 showed the agonist and antagonist properties of the ligands in stimulating $\left[{ }^{35} \mathrm{~S}\right] \mathrm{GTP} \gamma \mathrm{S}$ binding mediated by the $\kappa$ opioid receptor. Ligand 6 produced similar maximal stimulation of $\left[{ }^{35} \mathrm{~S}\right] \mathrm{GTP} \gamma \mathrm{S}$ binding $\left(E_{\max }\right)$ comparable to that of butorphan (1) and nalbuphine (2), but less than that of selective agonist $\mathrm{U} 50,488$. The $\mathrm{EC}_{50}$ value of this ligand is slightly higher than butorphan (1), but much lower than nalbuphine (2). Contrasted to the parent compounds, butorphan (1) and nalbuphine (2), ligand $\mathbf{6}$ can inhibit U50,488-stimulated $\left[{ }^{35} \mathrm{~S}\right] \mathrm{GTP} \gamma \mathrm{S}$ binding although it had a high $\mathrm{IC}_{50}$ value, which suggests that this ligand was a $\kappa$ agonist/antagonist.

Ligand 7 produced similar maximal stimulation of $\left[{ }^{35} \mathrm{~S}\right] \mathrm{GTP} \gamma \mathrm{S}$ binding $\left(E_{\mathrm{max}}\right)$ compared to that of butorphan (1), but was higher than that of naltrexone (3). Contrasted with the parent compound naltrexone (3), ligand 7 did not inhibit U50,488-stimulated $\left[{ }^{35} \mathrm{~S}\right] \mathrm{GTP} \gamma \mathrm{S}$, suggesting that this ligand was $x$ agonist.

The agonist and antagonist properties of these ligands in stimulating $\left[{ }^{35} \mathrm{~S}\right] \mathrm{GTP} \gamma \mathrm{S}$ binding mediated by the $\mu$ opioid receptor are shown in Table 3. Ligand $\mathbf{6}$ produced minimal stimulation of $\left[{ }^{35} \mathrm{~S}\right] \mathrm{GTP} \gamma \mathrm{S}$ binding mediated by $\mu$ receptor while it produced complete inhibition $(I)$ of the DAMGO stimulated $\left[{ }^{35}\right.$ max S]GTP $\gamma S$ binding comparable to that of butorphan (1) and nalbuphine (2). These data indicates that ligand $\mathbf{6}$ is a $\mu$ antagonist. Ligand 7 produced similar maximal stimulation of $\left[{ }^{35} \mathrm{~S}\right] \mathrm{GTP} \gamma \mathrm{S}$ binding $\left(E_{\max }\right)$ and maximal inhibition $(I)$ of the DAMGO stimulated [ ${ }^{35}$ max S]GTP $\gamma \mathrm{S}$ binding mediated by $\mu$ receptor comparable to that of butorphan (1), while producing higher maximal stimulation of $\left.{ }^{35} \mathrm{~S}\right] \mathrm{GTP} \gamma \mathrm{S}$ binding $\left(E_{\max }\right)$ and lower maximal inhibition $\left(I_{\max }\right)$ of the DAMGO-stimulated $\left[{ }^{35} \mathrm{~S}\right] \mathrm{GTP} \gamma \mathrm{S}$ binding mediated by $\mu$ receptor comparable to that of naltrexone (3). The data indicates that ligand 7 is a $\mu$ agonist/antagonist.

\section{Conclusions}

Heterodimeric ligands were synthesized containing $\kappa$ agonist and $\mu$ agonist/antagonist pharmacophores at one end joined by a 10 carbon linker chain containing $\mu$ antagonists pharmacophores (naltrexone, naloxone and nalbuphine) at the other end. These ligands were evaluated in vitro by their binding affinity at opioid receptors. Ligands (6-8) either displayed slightly better or retained the same affinity at $\boldsymbol{\kappa}$ and $\mu$ receptors compared to the monovalent ligands 1-5. Ligands 6-8 showed reduced affinity at $\delta$ receptor compared to the monovalent ligands $\mathbf{1}$ and $\mathbf{5}$. Functional assays showed that the ligand $\mathbf{6}$ was a $\kappa$ agonist/antagonist and $\mu$ antagonist, while ligand 7 was a $\kappa$ agonist and $\mu$ agonist/antagonist.

A possible explanation for the lower affinity at the $\kappa$ receptor displayed by ligand $\mathbf{5}$ (butorphan (1) with alkyl side chain) in comparison to butorphan 1 would be that the side chain in $\mathbf{5}$ hinders robust binding of the ligand at the $\kappa$ and $\mu$ receptor site. Similarly the higher affinity at $\boldsymbol{\kappa}$ receptor for the bivalent ligands 6-8 containing butorphan (1) (a high 
affinity $\kappa$ receptor ligand), a 10-carbon linking chain, and a $\mu$ antagonist ligand such as nalbuphine, naltrexone or naloxone, could be attributed to the higher binding affinity of both butorphan (1) at the $\kappa$ site and the $\mu$ antagonist (nalbuphine, naltrexone or naloxone) at the $\mu$ receptor site.

These ligands either retained or displayed better affinity at $\kappa, \mu$ and $\delta$ receptors compared to the reference compounds. These heterodimeric ligands could serve as probes of the opioid receptor-oligomerization phenomena and represent a useful starting point in the synthesis of a new generation of ligands endowed with analgesic effects with minor tolerance and dependence. Potential medications for cocaine abuse requiring both $\kappa$ agonist and $\mu$ antagonist, ${ }^{13,21}$ require further pharmacological studies to confirm these observations.

\section{Experimental Section}

Melting points were determined on a Thomas-Hoover capillary tube apparatus and are reported uncorrected. ${ }^{1} \mathrm{H}$ and ${ }^{13} \mathrm{CNMR}$ spectra were recorded on a Bruker AC300 spectrometer using tetramethylsilane as an internal reference. Element analyses, performed by Atlantic Microlabs, Atlanta, GA, were within $0.4 \%$ of theoretical values. Analytical thinlayer chromatography (TLC) was carried out on $0.2 \mathrm{~mm}$ Kieselgel 60F 254 silica gel plastic sheets (EM Science, Newark). Flash chromatography was used for the routine purification of reaction products. The column output was monitored by TLC.

\section{General Procedure for the Preparation of Ligands 6-8}

The acid $5(0.6 \mathrm{mmol})$ and an appropriate opioid $(0.5 \mathrm{mmol})$ were dissolved in anhydrous dichloromethane $(15 \mathrm{~mL})$ under nitrogen. A catalytic amount of 4-dimethylaminopyridine was added, followed by $N, N$-dicyclohexylcarbodiimide $(0.6 \mathrm{mmol})$. The solution mixture was stirred at room temperature overnight, the solid was filtered off and the crude product was purified by column chromatography on silica gel (EtOAc : $\left.\mathrm{Et}_{3} \mathrm{~N}, 100: 1\right)$ to afford the corresponding bivalent ligands.

(5a, 6a)-17-(cyclobutylmethyl)-6, 14-dihydroxy-4, 5-epoxymorphinan-3-yl 17(cyclobutylmethyl)morphinan-3-yl sebacoylate (6)—colorless oil (40.4\%). ${ }^{1} \mathrm{HNMR}$ $\left(300 \mathrm{~Hz}, \mathrm{CDCl}_{3}\right): 7.10(\mathrm{~d}, J=8.4 \mathrm{~Hz}, 1 \mathrm{H}), 6.92(\mathrm{~d}, J=2.1 \mathrm{~Hz}, 1 \mathrm{H}), 6.85(\mathrm{dd}, J=8.1 \mathrm{~Hz}, 2.1 \mathrm{~Hz}$, $1 \mathrm{H}), 6.78(\mathrm{~d}, J=8.1 \mathrm{~Hz}, 1 \mathrm{H}), 6.65(\mathrm{dd}, J=8.1 \mathrm{~Hz}, 2.4 \mathrm{~Hz}, 1 \mathrm{H}), 4.64(\mathrm{~d}, J=5.1 \mathrm{~Hz}, 1 \mathrm{H}), 4.60(\mathrm{~d}$, $J=4.8 \mathrm{~Hz}, 1 \mathrm{H}), 4.17-4.08(\mathrm{~m}, 2 \mathrm{H}), 3.12(\mathrm{~d}, \mathrm{~J}=18.9 \mathrm{~Hz}, 1 \mathrm{H}), 3.02(\mathrm{~d}, \mathrm{~J}=18.9 \mathrm{~Hz}, 1 \mathrm{H})$, 2.85-1.05(m, 59H). ${ }^{13} \mathrm{CNMR}\left(75 \mathrm{~Hz}, \mathrm{CDCl}_{3}\right): 172.3,171.5,149.2,148.5,141.9,135.1$, $132.9,131.3,130.7,128.4,121.5,118.7,118.4,118.0,91.6,69.9,66.5,62.9,61.4,60.5$, $55.8,46.1,45.6,44.8,43.6,41.7,37.7,36.5,34.8,34.3,33.8,33.6,32.6,32.0,30.8,28.9$, 28.8, 27.7, 26.8, 26.69, 26.65, 26.4, 26.3, 24.8, 24.7, 24.3, 23.9, 23.3, 22.0, 18.7, 18.6, 14.1. Anal. $\left(\mathrm{C}_{52} \mathrm{H}_{70} \mathrm{~N}_{2} \mathrm{O}_{7} \cdot 0.5 \mathrm{H}_{2} \mathrm{O}\right) \mathrm{C}, \mathrm{H}, \mathrm{N}$.

17-(cyclopropylmethyl)morphinan-3-yl(5a)-17-(cyclopropylmethyl)-14hydroxy-6-oxo-4,5-epoxymorphiana-3-yl sebacoylate (7)—colorless oil (48.4\%). ${ }^{1} \mathrm{HNMR}\left(300 \mathrm{~Hz}, \mathrm{CDCl}_{3}\right): 7.10(\mathrm{~d}, J=8.1 \mathrm{~Hz}, 1 \mathrm{H}), 6.92(\mathrm{~d}, J=2.1 \mathrm{~Hz}, 1 \mathrm{H}), 6.85(\mathrm{dd}$, $J=8.1 \mathrm{~Hz}, 3 \mathrm{~Hz}, 2 \mathrm{H}), 6.68(\mathrm{~d}, J=8.4 \mathrm{~Hz}, 1 \mathrm{H}), 4.69(\mathrm{~s}, 1 \mathrm{H}), 3.21(\mathrm{~d}, J=5.7 \mathrm{~Hz}, 1 \mathrm{H}), 3.12-0.84(\mathrm{~m}$, $55 \mathrm{H}), 0.57(\mathrm{~d}, J=7.5 \mathrm{~Hz}, 2 \mathrm{H}), 0.16(\mathrm{~d}, J=4.8 \mathrm{~Hz}, 2 \mathrm{H}) .{ }^{13} \mathrm{CNMR}\left(75 \mathrm{~Hz}, \mathrm{CDCl}_{3}\right): 207.6,172.4$, 171.3, 149.2, 147.7, 142.0, 135.2, 132.6, 130.09, 130.07, 128.4, 122.8, 119.2, 118.5, 118.1, $90.6,70.0,61.9,61.5,59.2,55.8,50.6,45.6,44.9,41.8,37.7,36.5,36.0,34.9,34.4,33.9$, $31.2,30.7,29.03,29.00,28.9,27.8,26.7,26.5,24.8,24.7,24.4,22.9,22.1,18.8,9.3,4.0$, 3.8. Anal. $\left(\mathrm{C}_{51} \mathrm{H}_{66} \mathrm{~N}_{2} \mathrm{O}_{7} \cdot 1.5 \mathrm{H}_{2} \mathrm{O} \cdot 2 \mathrm{HCl}\right) \mathrm{C}, \mathrm{H}, \mathrm{N}$. 
(5a)-17-allyl-14-hydroxy-6-oxo-4,5-epoxymorphinan-3-yl-17-

(cyclobutylmethyl)morphinan-3-yl sebacoylate (8)—pink solid (22.9

\%). ${ }^{1} \mathrm{HNMR}\left(300 \mathrm{~Hz}, \mathrm{CDCl}_{3}\right): 7.10(\mathrm{~d}, J=8.1 \mathrm{~Hz}, 1 \mathrm{H}), 6.92(\mathrm{~s}, J=2.1 \mathrm{~Hz}, 1 \mathrm{H}), 6.85(\mathrm{dd}$, $J=8.1 \mathrm{~Hz}, 1.5 \mathrm{~Hz}, 2 \mathrm{H}), 6.70(\mathrm{~d}, J=8.4 \mathrm{~Hz}, 1 \mathrm{H}), 5.86-5.75(\mathrm{~m}, 1 \mathrm{H}), 5.26-5.17(\mathrm{~m}, 2 \mathrm{H}), 4.69(\mathrm{~s}$, $1 \mathrm{H}), 3.17-2.82(\mathrm{~m}, 6 \mathrm{H}), 2.65-0.93(\mathrm{~m}, 49 \mathrm{H}) .{ }^{13} \mathrm{CNMR}\left(75 \mathrm{~Hz}, \mathrm{CDCl}_{3}\right): 183.6,172.4,171.3$, 149.2, 147.7, 142.0, 135.1, 134.9, 132.6, 130.0, 129.9, 128.4, 122.9, 119.2, 118.4, 118.2, $118.1,90.5,70.1,62.0,61.4,57.6,55.8,50.5,45.6,44.7,43.1,41.6,37.7,36.5,36.0,34.8$, $34.3,33.9,32.7,31.1,30.5,29.0,28.9,27.9,27.8,26.7,26.5,24.7,24.6,24.4,24.0,23.0$, 22.1, 18.8. Anal. $\left(\mathrm{C}_{50} \mathrm{H}_{64} \mathrm{~N}_{2} \mathrm{O}_{7} \cdot 2 \mathrm{H}_{2} \mathrm{O}\right) \mathrm{C}, \mathrm{H}, \mathrm{N}$.

\section{Opioid Binding to the Human $\mu, \delta$ and $\mathrm{k}$ Opioid Receptors}

Chinese hamster ovary $(\mathrm{CHO})$ cells stably transfected with the human $\kappa$ opioid receptor (hKOR-CHO), $\delta$-opioid receptor (hDOR-CHO), and the $\mu$-opioid receptor (hMOR-CHO) were obtained from Drs. Larry Toll (SRI International, Palo Alto, CA) and George Uhl (NIDA Intramural Program, Bethesda, MD), respectively. The cells were grown in $100 \mathrm{~mm}$ dishes in Dulbecco's modified Eagle's media (DMEM) supplemented with 10\% fetal bovine serum (FBS) and penicillin-streptomycin $(10000$ units $/ \mathrm{mL})$ at $37^{\circ} \mathrm{C}$ in a $5 \% \mathrm{CO}_{2}$ atmosphere. The affinity and selectivity of the compounds for the multiple opioid receptors were determined by incubating the membranes with radiolabeled ligands and 12 different concentrations of the compounds at $25^{\circ} \mathrm{C}$ in a final volume of $1 \mathrm{~mL}$ of $50 \mathrm{mM}$ Tris- $\mathrm{HCl}, \mathrm{pH}$ 7.5. Incubation times of $60 \mathrm{~min}$ were used for the $\mu$-selective peptide $\left[{ }^{3} \mathrm{H}\right] \mathrm{DAMGO}$ and the $\kappa$-selective ligand $\left[{ }^{3} \mathrm{H}\right] \mathrm{U} 69,593$. A $3 \mathrm{~h}$ incubation was used with the $\delta$-selective antagonist $\left[{ }^{3} \mathrm{H}\right]$ naltrindole.

\section{[35S]GTPyS Binding Studies To Measure Coupling to G Proteins}

Membranes from CHO cells stably expressing either the human $\kappa$ or $\mu$ opioid receptor were used in the experiments. Cells were scraped from tissue culture plates and then centrifuged at $1000 \mathrm{~g}$ for $10 \mathrm{~min}$ at $4^{\circ} \mathrm{C}$. The cells were resuspended in phosphate-buffered saline, $\mathrm{pH}$ 7.4, containing $0.04 \%$ EDTA. After centrifugation at $1000 \mathrm{~g}$ for $10 \mathrm{~min}$ at $4^{\circ} \mathrm{C}$, the cell pellet was resuspended in membrane buffer, which consisted of $50 \mathrm{mM}$ Tris- $\mathrm{HCl}, 3 \mathrm{mM} \mathrm{MgCl} 2$, and $1 \mathrm{mM}$ EGTA, pH 7.4. The membranes were homogenized by with a Dounce homogenizer, followed by centrifugation at $40000 \mathrm{~g}$ for $20 \mathrm{~min}$ at $4^{\circ} \mathrm{C}$. The membrane pellet was resuspended in membrane buffer, and the centrifugation step was repeated. The membranes were then resuspended in assay buffer, which consisted of $50 \mathrm{mM}$ Tris- $\mathrm{HCl}, 3$ $\mathrm{mM} \mathrm{MgCl} 2,100 \mathrm{mM} \mathrm{NaCl}$, and $0.2 \mathrm{mM}$ EGTA, $\mathrm{pH}$ 7.4. The protein concentration was determined by the Bradford assay using bovine serum albumin as the standard. The membranes were frozen at $-80^{\circ} \mathrm{C}$ until use.

CHO cell membranes expressing either the human $\kappa$ opioid receptor $(15 \mu \mathrm{g}$ of protein per tube) or $\mu$ opioid receptor (7.5 $\mu \mathrm{g}$ of protein per tube) were incubated with 12 different concentrations of the agonist in assay buffer for $60 \mathrm{~min}$ at $30^{\circ} \mathrm{C}$ in a final volume of $0.5 \mathrm{~mL}$. The reaction mixture contained $3 \mu \mathrm{M}$ GDP and $80 \mathrm{pmol}$ of $\left[{ }^{35} \mathrm{~S}\right] \mathrm{GTP} \gamma \mathrm{S}$. Basal activity was determined in the presence of $3 \mu \mathrm{M}$ GDP and in the absence of an agonist, and nonspecific binding was determined in the presence of $10 \mu \mathrm{M}$ unlabeled GTP $\gamma \mathrm{S}$. Then, the membranes were filtered onto glass fiber filters by vacuum filtration, followed by three washes with 3 $\mathrm{mL}$ of ice-cold $50 \mathrm{mM}$ Tris-HCl, $\mathrm{pH}$ 7.5. Samples were counted in $2 \mathrm{~mL}$ of Ecoscint A scintillation fluid. Data represent the percent of agonist-stimulation $\left[{ }^{35} \mathrm{~S}\right] \mathrm{GTP} \gamma \mathrm{S}$ binding over the basal activity, defined as [(specific binding/basal binding $) \times 100]-100$. All experiments were repeated at least three times and were performed in triplicate. To determine antagonist activity of a compound at the $\mu$ opioid receptors, $\mathrm{CHO}$ membranes expressing the $\mu$ opioid receptor were incubated with the compound in the presence of 200 $\mathrm{nM}$ of the agonist DAMGO. To determine antagonist activity of a compound at the $\mathrm{x}$ opioid 
receptors, $\mathrm{CHO}$ membranes expressing the $\mathrm{\kappa}$ opioid receptor were incubated with the compound in the presence of $100 \mathrm{nM}$ of the $\mathrm{x}$ agonist U50,488.

\section{Supplementary Material}

Refer to Web version on PubMed Central for supplementary material.

\section{Acknowledgments}

This work was supported in part by NIH Grants RO1-DA14251 (JLN) and K05-DA 00360 (JMB). Levorphanol tartrate was generously donated by Mallinckrodt Inc.

\section{Abbreviations}

Butorphan (-) 3-hydroxy- $N$-cyclobutylmethylmorphinan

U-50488 $\quad$ trans $(1 \mathrm{~s}, 2 \mathrm{~s})-3$, 4-dichloro- $N$-methyl- $N$-[2-(1-pyrrolidinyl)cyclohexyl]benzeneacetamide

U-69593 (+)(5a, 7a, 8ß)- $N$-methyl- $N$-[7-(1-pyrrolidinyl)-1-oxaspiro[4,5]dec-8-yl]benzeneacetamide

DAMGO $\quad\left[D\right.$-Ala ${ }^{2}, N$-Me-Phe ${ }^{4}$, Gly-ol $\left.{ }^{5}\right]$-enkephalin

\section{References}

(1). Brady LS, Devi LA. Dimerization of G-protein-coupled receptors: Implications for drug design and signaling. Neuropsychopharmacol. 2000; 23:S1-S77.

(2). Devi LA. Heterodimerization of G-protein-coupled receptors: pharmacology, signaling and trafficking. Trends Pharmacol. Sci. 2001; 22:532-537. [PubMed: 11583811]

(3). Gomes I, Jordan BA, Gupta A, Rois C, Trapaidze N, Devi LA. G-Protein coupled receptor dimerization : implications in modulating receptor function. J. Mol. Chem. 2001; 79:226-242.

(4). Morphy R, Kay C, Rankovic Z. From magic bullets to designed multiple ligands. Drug Discovery Today. 2004; 9:641-651. [PubMed: 15279847]

(5)a). Cvejic S, Devi L. Dimerization of the $\delta$ Opioid Receptor: Implication for a role in receptor internalization. J. Biol. Chem. 1997; 272:26959-26964. [PubMed: 9341132] b) Jordan BA, Cvejic S, Devi LA. Opioids and their complicated receptor complexes. Neuropsychopharm. 2000; 23:S15-S18.c) George SR, Fan T, Xie Z, Tse R, Tamni V, Varghese G, O’Dowd BF. Oligomerization of $\mu$ - and $\delta$-opioid receptors: generation of novel functional properties. J. Biol. Chem. 2000; 275:26128-26135. [PubMed: 10842167]

(6)a). Portoghese PS, Ronsisvalle G, Larson DL, Yim CB, Sayre LM, Takemori AE. Opioid agonist and antagonist bivalent ligands as receptor probes. Life Sci. 1982; 31:1283. [PubMed: 6292615] b) Erez M, Takemori AE, Portoghese PS. Narcotic antagonistic potency of bivalent ligands which contain beta-naltrexamine. Evidence for bridging between proximal recognition sites. J. Med. Chem. 1982; 25:847-849.c) Portoghese PS, Larson DL, Sayre LM, Yim CB, Ronsisvalle G, Tam SW, Takemori AE. Opioid agonist and antagonist bivalent ligands. The relationship between spacer length and selectivity at multiple opioid receptors. J. Med. Chem. 1986; 29:1855-1861. [PubMed: 3020244] d) Portoghese PS, Nagase H, Takemori AE. Only one pharmacophore is required for the $\kappa$ opioid antagonist selectivity of norbinaltorphimine. J. Med. Chem. 1988; 31:1344-1347. [PubMed: 2838632] e) Portoghese PS, Ronsisvalle G, Larson DL, Takemori AE. Synthesis and opioid antagonist potencies of naltrexamine bivalent ligands with conformationally restricted spacers. J. Med. Chem. 1986; 29:1650-1653. [PubMed: 3018242] f) Portoghese PS, Larson DL, Yim CB, Sayre LM, Ronsisvalle G, Lipkowski AW, Takemori AE, Rice KC, Tam SW. Stereostructure-activity relationship of opioid agonist and antagonist bivalent ligands. Evidence for bridging between vicinal opioid receptors. J. Med. Chem. 1985; 28:11401141. [PubMed: 2993609] 
(7). Lalchandani SG, Lei L, Zheng W, Suni MM, Moore BM, Liggett SB. Yohimbine dimers exhibiting selectivity for the human alpha 2C-adrenoceptor subtype. J. Pharmacol. Exp. Ther. 2002; 303:979-984. [PubMed: 12438517]

(8). Abadi AH, Lankow S, Hoefgen B, Decker M, Kassak MU, Lehmann J. Dopamine/serotonin receptor ligands, part III [1]: synthesis and biological activities of 7, $7^{\prime}$-alkylene-bis-6, 7, 8, 9, 14, 15-hexahydro-5H-benz $[d]$ indolo[2, 3-g]azecines-application of the bivalent ligand approach to a novel type of dopamine receptor antagonist. Arch. Pharm. (Pharm. Med. Chem.). 2002; 335:367-373.

(9)a). Halazy S, Perez M, Fourrier C, Pallard I, Pauwels PJ, Palmier C. Serotonin dimers : application of the bivalent ligand approach to the design of new potent and selective 5-HT (1B/1D)agonists. J. Med. Chem. 1996; 39:4920-4927. [PubMed: 8960551] b) Perez M, Jorand-Lebrun C, Pauwels PJ, Pallard I, Halazy S. Dimers of 5HT1ligands preferentially bind to 5HT1B/1D receptor subtypes. Bioorg. Med. Chem. Lett. 1998; 8:1407-1412. [PubMed: 9871775] c) Perez M, Pauwels PJ, Fourrier C, Chopin P, Valentin JP, John GW. Dimerization of sumatriptan as an efficient way to design a potent, centrally and orally active 5-HT1B agonist. Bioorg. Med. Chem. lett. 1998; 8:675-680. [PubMed: 9871581]

(10)a). Christopoulos A, Grant MK, Ayoubzadeh N, Kim ON, Sauerberg P, Jeppesen L. Synthesis and pharmacological evaluation of dimeric muscarinic acetylcholine receptor agonists. J. Pharmacol. Exp. Ther. 2001; 298:1260-1268. [PubMed: 11504829] b) Rajeswaran WG, Cao Y, Huang XP, Wroblewski ME, Colclough T, Lee S. Design, synthesis, and biological characterization of bivalent 1-methyl-1,2,5,6-tetrahydropyridyl-1,2,5-thiadiazole derivatives as selective muscarinic agonist. J. Med. Chem. 2001; 44:4563-4576. [PubMed: 11741475] c) Messer WS, Rajeswaran JR, Cao WG, Zhang Y, El-Assadi HJ, Dochery AA. Design and development of selective muscarinic agonists for the treatment of Alzheimer's disease: characterizaiton of tetrahydropyrimidine derivatives and development of new approaches for improved affinity and selectivity for M1 receptors. Pharm. Acta. Helv. 2000; 74:135-140. [PubMed: 10812950]

(11). Decker M. Homobivalent quinazolinimines as novel nanomolar inhibitors of cholinesterases with dirigible selectivity toward butyrylcholinesterase. J. Med. Chem. 2006; 49:5411-5413. [PubMed: 16942014]

(12). Owens J. Bridging the GPCR gap. Nature Rev. Drug Discov. 2006; 5:105.

(13). Neumeyer JL, Bidlack JM, Zong R, Bakthavachalam V, Gao P, Cohen DJ, Negus SS, Mello NK. Synthesis and opioid receptor affinity of morphinan and benzomorphan derivatives: mixed kappa agonists and $m u$ agonists/antagonists as potential pharmacotherapeutics for cocaine dependence. J. Med. Chem. 2000; 43:114-122. [PubMed: 10633042]

(14). Gates M, Montzka TA. Some morphine antagonists possessing high analgesic activity. J. Med. Chem. 1964; 7:127-131. [PubMed: 14187361]

(15). Neumeyer JL, Zhang A, Xiong W, Gu X, Hilbert JE, Knapp BI, Negus SS, Mello NK, Bidlack JM. Design and synthesis of novel dimeric morphinan ligands for $\kappa$ and $\mu$ opioid receptors. J. Med. Chem. 2003; 46:5162-5170. [PubMed: 14613319]

(16). Mathews JL, Peng X, Xiong W, Zhang A, Negus SS, Neumeyer JL, Bidlack JM. Characterization of a novel bivalent morphinan possessing $\kappa$ agonist and $\mu$ agonist/antagonist properties. J. Pharmacol. Exp. Ther. 2005; 315:821-827. [PubMed: 16076937]

(17). Peng X, Knapp BI, Bidlack JM, Neumeyer JL. Synthesis and preliminary in vitro investigation of bivalent ligands containing homo- and heterodimeric pharmacophores at $\mu, \delta$ and $\kappa$ opioid receptors. J. Med. Chem. 2006; 49:256-262. [PubMed: 16392810]

(18). Neumeyer JL, Peng X,M, Knapp BI, Bidlack JM, Lazarus LH, Salvadori S, Trapella C, Bolboni G. New opioid designed multiple ligand form Dmt-Tic and morphinan pharmacophores, J. Med. Chem. 2006; 49:5640-5643.

(19). Portoghese PS. From Models to Molecules: Opioid Receptor Dimers, Bivalent Ligands, and Selective Opioid Receptor Probes. J. Med. Chem. 2001; 44:2259-2269. [PubMed: 11428919]

(20). Daniels JD, Kulkarni A, Xie Z, Bhushan RG, Portoghese PS. A Bivalent Lignd(KDAN-18) Containing $\delta$-Antagonist and $\kappa$-Agonist Pharmacophores Bridges $\delta_{2}$ and $\kappa_{1}$ Opioid Receptor Phenotypes. J. Med. Chem. 2005; 48:1713-1716. [PubMed: 15771416]

(21). Archer S, Glick SD, Bidlack JM. Cyclozocine revisited. Neurochem. Res. 1996; 21:1369-1373. [PubMed: 8947927] 

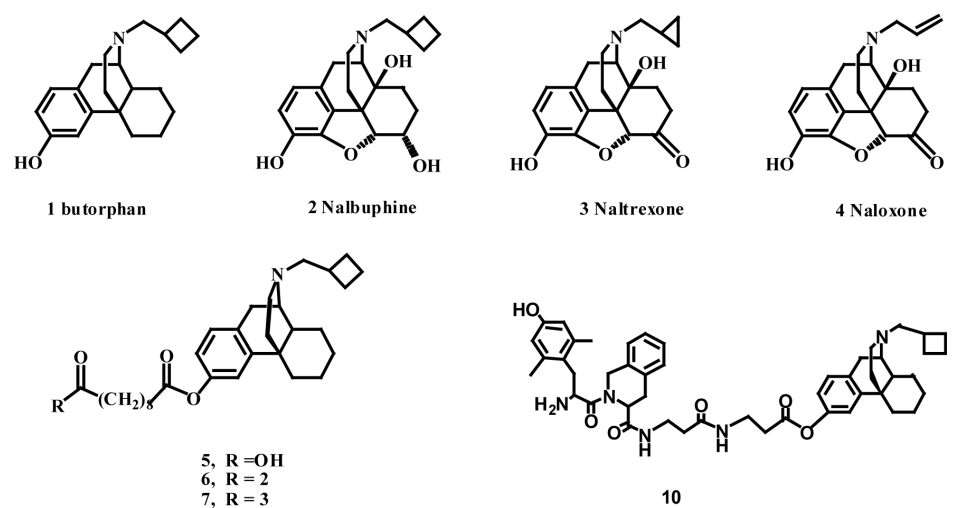

5, R $=\mathrm{OH}$
$6, \mathrm{R}=\mathbf{2}$
$7, \mathrm{R}=\mathbf{3}$
$\mathbf{8}, \mathrm{R}=\mathbf{4}$
$9, \mathrm{R}=\mathbf{1}$

10

Fig. 1.

Structures of opioids and bivalent ligands 


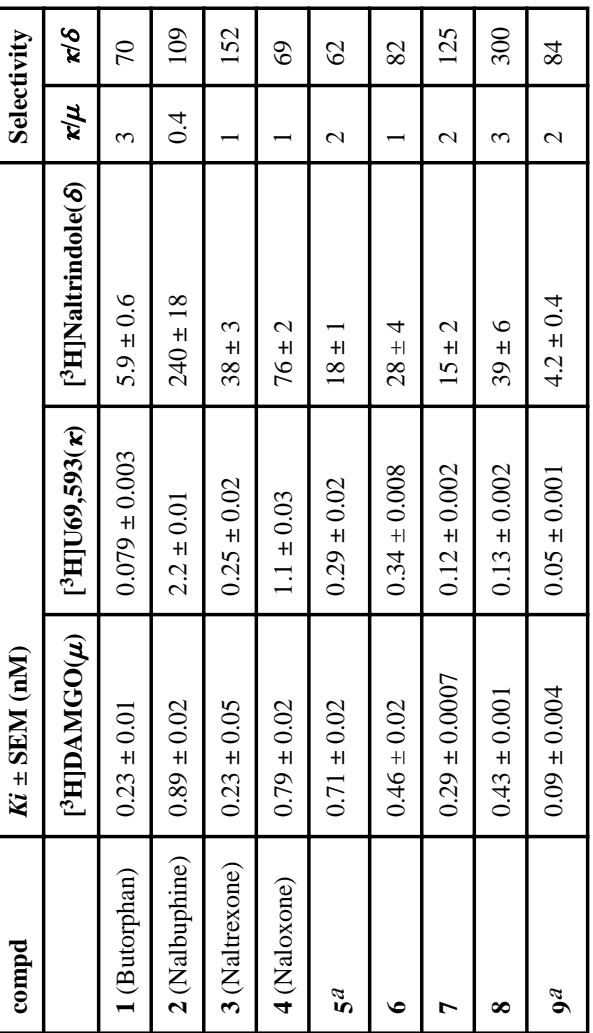




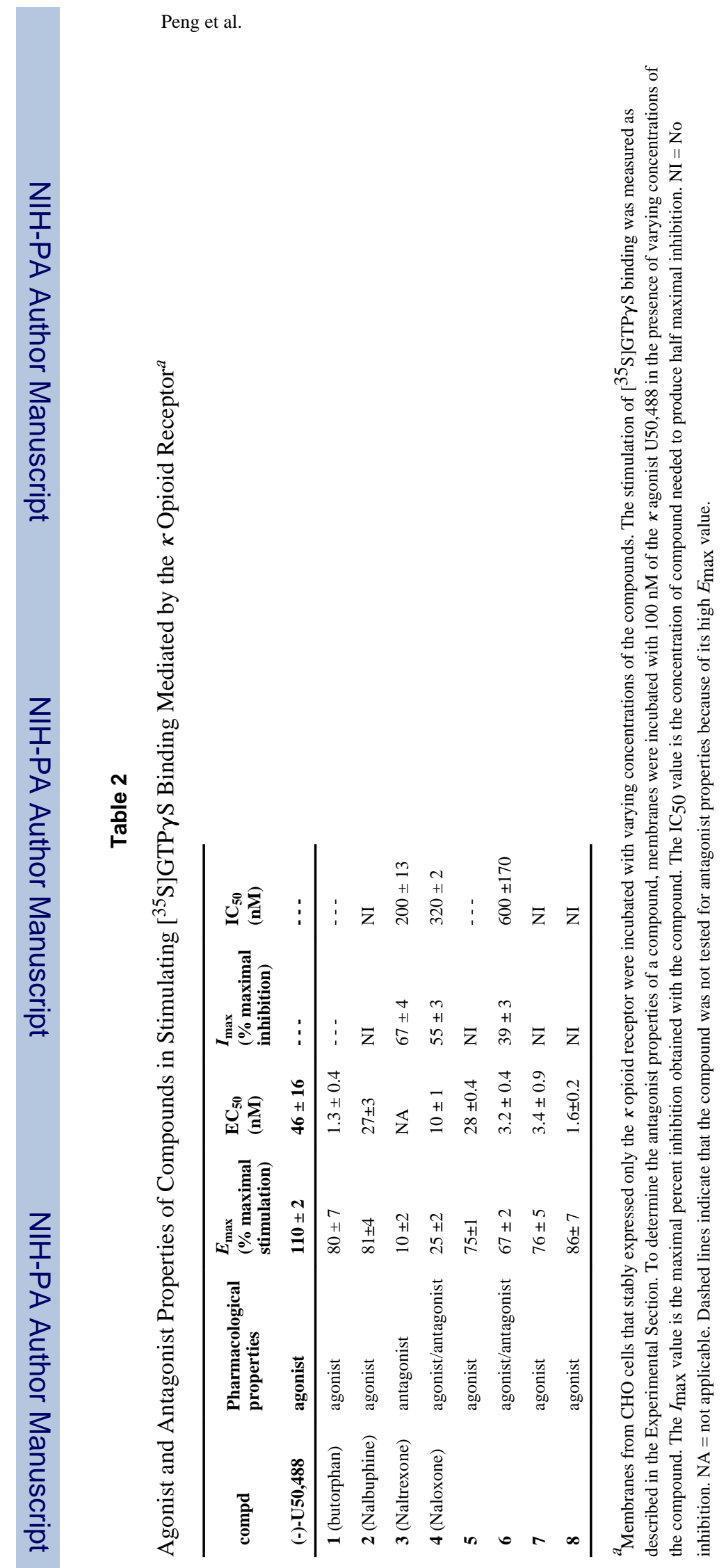

JMed Chem. Author manuscript; available in PMC 2012 May 22. 


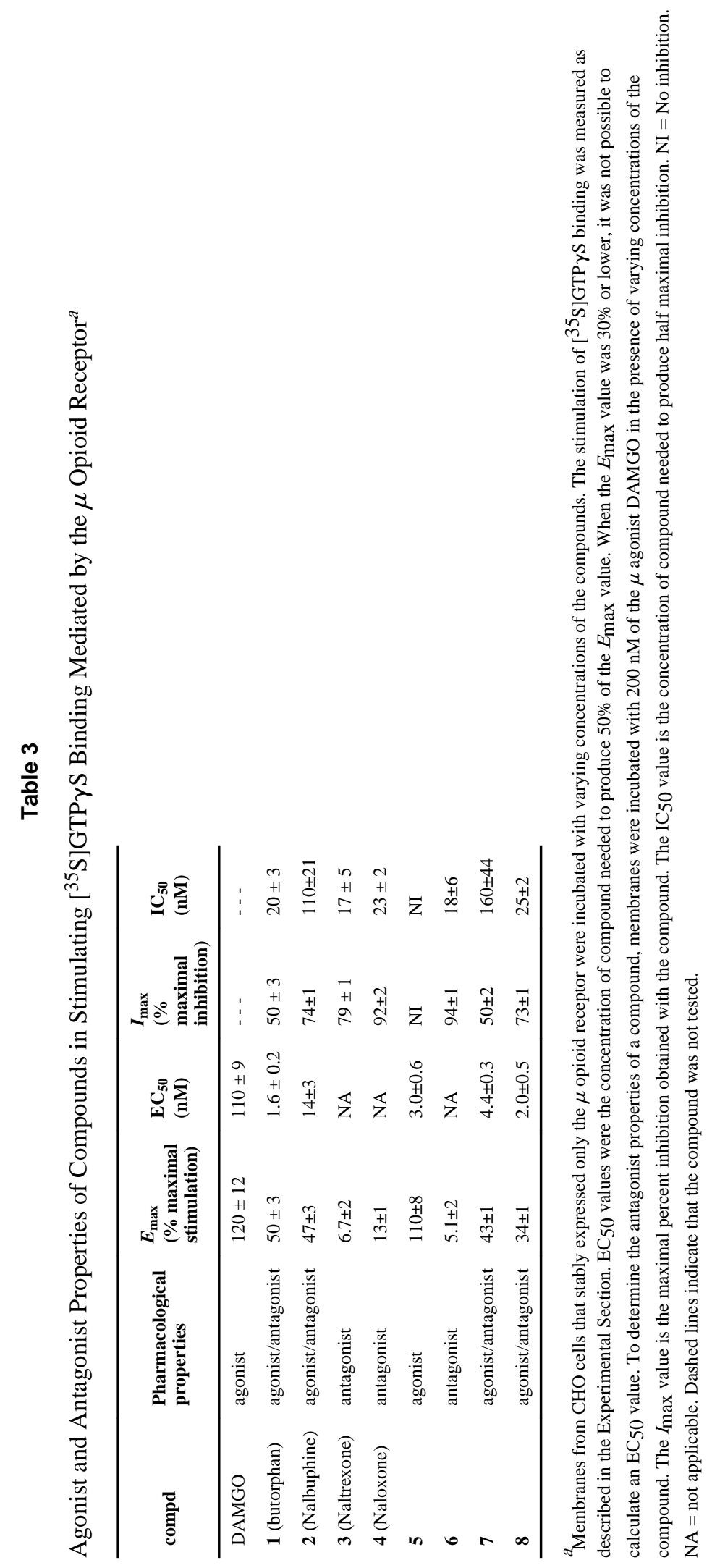

